\title{
Proposal of a new system to classify possible damages in piles partially reinforced considering the results of low strain integrity tests
}

\section{Proposta de novo sistema de classificação de possíveis danos em estacas parcialmente armadas a partir de resultados de ensaios $P I T$}
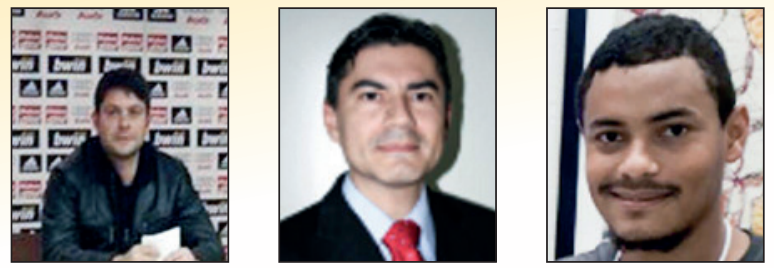

R. P. S. PASQUAL a rodrigo@protecengenharia.com.br https://orcid.org/0000-0001-8667-066X

$\begin{array}{r}\text { A. C. M. KORMANN } \\ \text { alessander@ufpr.br }\end{array}$
https://orcid.org/0000-0002-4512-3763
T. F. DE SOUZA JUNIOR ${ }^{\text {b }}$
tennisonufpr@outlook.com
https://orcid.org/0000-0003-0235-3152

\begin{abstract}
Low strain integrity tests in piles are relatively cheap, of quick execution and nondestructive. Despite all these advantages, several variables are involved and the influence of external factors can complicate the interpretation of the results. Between them, the influence of the pile reinforcement can be high lighted. In piles partially reinforced, the difference in density and elastic modulus of the concrete in different parts of the pile and the influence of the process of introducing the reinforcement bars can induce some reflections in the test that can be confused with damage in the pile and, therefore, should be taken into account to analyze the tests results. In this research, the influence of the reinforcement embedded in the piles is analyzed using numerical (FEM) simulations and comparing them with tests made in the field. A new classification of possible damages is proposed based on the analysis of the reflections observed at the end of the reinforcement cage embedded in a pile partially reinforced.
\end{abstract}

Keywords: piles, PIT, reinforcement effects.

\section{Resumo}

Os ensaios PIT para avaliação de integridade em estacas têm um custo relativamente baixo, são de rápida execução e não destrutivos. Apesar dessas vantagens, as inúmeras variáveis envolvidas e a influência de fatores externos podem tornar a interpretação dos resultados complicada. Dentre elas, destacam-se as armaduras das estacas. Em estacas parcialmente armadas, a variação de densidade e de módulo de elasticidade entre o trecho armado e não armado e eventuais alterações na interface decorrentes do processo de introdução da armadura podem gerar reflexões que podem ser confundidas com danos nas estacas e devem ser levadas em conta na análise dos resultados. Neste trabalho a influência da armadura inserida nas estacas é avaliada com auxílio de simulações numéricas por elementos finitos e comparação com resultados de ensaios PIT executados em campo. Um novo sistema de classificação de possíveis danos é proposto para análise de reflexões nos sinais de ensaios PIT gerados na ponta da armadura inserida em estacas parcialmente armadas.

Palavras-chave: estacas, PIT, influência da armadura. 


\section{Introduction}

The risks associated with integrity problems in deep foundations led Brazilian and international standards to include the theme in their texts. Specifically for cast-in-place piles, the Brazilian standard determines visual inspections in $1 \%$ of the piles to verify the quality and integrity of the shaft. Although not required by the Brazilian standard, some companies have demanded from their suppliers the execution of low strain integrity tests in up to $100 \%$ of the piles [1]. The speed of execution and the relatively low cost are pointed out as main advantages of the test. However, interpretation of the results of these tests is often difficult especially when there are changes in the cross section of the piles or when there is influence of the surrounding soil [2].

The reinforcement exposed above the top of the pile and partially reinforced piles can generate changes in the signals obtained in the test and make it difficult to identify a damage [3]. One option to evaluate the results obtained in low strain integrity tests and the influence of these factors on the results is to simulate the test numerically or analytically and compare the theoretical result obtained with the result obtained in the field. Ordóñez e Botero [4] for example, using an analytical solution for the wave propagation equations, simulated the results that would be obtained in intact piles and in piles with cross section variations under various conditions. Ambrosini and Ezeberry [5] and Chai, Wei, Phoon and Yang [6] published results obtained in numerical simulations by modeling the pile as a bar and the ground as springs and dampers obtaining a good correspondence between the simulation and practical results in the field. Some papers have recently been published simulating the test in three-dimensional numerical models with different objectives such as [2], [8], [9], [10], [11] and [12].

In this paper, finite elements numerical models developed by the author are used to evaluate the influence of the embedded reinforcement on partially reinforced piles in the low strain integrity test results. Comparisons are performed with field results. A new classification system of possible damages in the transition between reinforced and unreinforced parts of the piles is proposed different from those currently used as published by Liang and Rausche [13], Webster, Rausche and Webster [14] and Cunha, Camapum de Carvalho and Silva [15].

\section{Theoretical references}

In this item it is presented a brief summary of the theoretical background that supports the analyzes carried out in this paper with special emphasis on numerical simulations and the theoretical influence of pile reinforcement in the test.

\subsection{One-dimensional finite element simulation of the low strain integrity test}

Considering that the low strain integrity test can be approximated in a one-dimensional problem, some papers have been published simulating the test using finite elements method in a similar way to that originally proposed by Smith [16]. In this solution the pile is considered as a bar and the ground as a system of springs and dampers. The load applied in the top of the pile in the model (hammer impact simulation) cannot be considered as static since there is a variation of the force applied during the time in which the hammer remains in contact with the pile. Generally, it is considered a sine function considering only half of the waveform defined by Equation (1).

$\mathrm{F}(\mathrm{t})=\mathrm{F}_{\max } \operatorname{sen}(\pi) \frac{t}{t_{c}}$

Where:

$F(t)$ - Force in the instant " $t$ ";

$\mathrm{F}_{\text {max }}$ - Maximum force applied;

$\mathrm{t}_{\mathrm{c}}$ - Time in which hammer stays in contact with the top of the pile. The soil is simulated by assigning a spring and damper at the toe and shaft of the pile with properties calculated according to Equations (2) to (5).

$k_{v}=2.75 G_{s}$

$c_{v}=2 \pi \rho_{s} c_{s} r_{p}$

$\mathrm{C}_{v}=\frac{0.85 K_{v} r_{p}}{C_{s}}$

$\mathrm{K}_{v}=\frac{4 G_{s} r_{p}}{\left(1-v_{s}\right)}$

Where:

$\mathrm{k}_{\mathrm{v}}$ - Elastic stiffness of the spring that represents the soil in the pile shaft;

$\mathrm{G}_{\mathrm{s}}$ - Soil shear modulus [as the low strain integrity test generates low displacements it is recommended to use G0 (shear modulus in low strains)];

$\mathrm{C}_{\mathrm{v}}$ - damping coefficient in the pile shaft (lateral);

$\rho_{\mathrm{s}}$ - Specific mass of the soil;

$\mathrm{C}_{\mathrm{s}}$ - the "S" waves speed in the soil;

$r_{p}$ - radius of the pile (in $m$ );

$\mathrm{C}_{v}$ - damping coefficient in the pile toe.

$\mathrm{K}_{\mathrm{v}}$ - Elastic stiffness of the spring that represents the soil in the pile toe;

$v_{\mathrm{s}}$ - Soil Poisson`s ratio.

Equations (2) to (5), based on the studies of Lysmer and Richart [17], Novak [18] and Simons and Randolph [19], are derived assuming a hard disk in an elastic plane. According to $\mathrm{Yu}$ and Liao [20] the errors introduced by this simplification are small. The problem is then solved by subdividing the domain into smaller parts (finite elements) each one represented by a set of equations. According to Hetland [11], the response of each element is characterized by its degrees of freedom and defined by equations whose solutions can be obtained by methods of direct integration in the time domain such as those of Newmark and Hilber, Hughes and Taylor [22]. For each defined time interval, using the methods described, the displacement, velocity and acceleration at the points that define the finite elements are obtained. The velocity variation (particle velocity) over time at the point defining the top of the pile can then be obtained and compared to the reflectograms obtained in the field tests. 


\subsection{Tri-dimensional finite element simulation of the low strain integrity test}

Theoretically, in one-dimensional simulations of low strain integrity tests, the load is considered applied at the top of the pile and the effects resulting from the location of the impact at the top of the pile are not taken into account, nor the effects resulting from the relation between the contact area of the hammer and the area of the top of the pile neither the effects arising from the radiation of the waves near the top of the pile.

In addition, it is necessary: the assignment of boundary conditions (the representation of the soil in the model is limited representing just a part of a mass that has continuity in practice), the constitutive model of the soil and contact conditions in the soil-pile interface. All these are relevant issues in 3-D models that are not taken into account in 1-D models.

In 3-D simulations, the soil can also be modeled by finite elements rather than replaced by springs and dampers. This makes even more important the care with discretization of the finite elements. According to Hetland [11] in dynamic analysis a division into very large elements can result in imprecision of the results with filtration of the higher frequencies and a division into very small elements increases the computational processing time significantly.

With the numerical model defined, in a similar way to what occurs in the one-dimensional model, the displacements, velocities and accelerations in each point of the model are obtained with the solution of the general equation of structural dynamics derived from Newton's second law using one of the known integration methods. Liao and Roesset [23] compared the results obtained by the finite element method in 1-D and 3-D models, concluding that, in general terms, the results are similar. In the 3-D models, however, there is a tendency of more high-frequency oscillations in the velocity reflectograms. A pile can be considered by approximation a onedimensional elastic bar in low strain integrity test simulations if it satisfies two conditions: the wavelength is greater than the diameter and smaller than the length of the pile [7].

\subsection{The influence of the reinforcement in the results interpretation}

At the moment that a hammer blow is applied in the top of the pile in the test, a transient tension pulse is generated, and its effect is propagated along the pile. Due to the inertia of the element, the strain and deformations caused by the force radiate from the point of application to all directions. Any point in the pile will be in complete rest before and after all effects of the generated impact are dissipated. This phenomenon is called the propagation of a tension wave. There are generally three types of tension waves generated when some sudden movement in an elastic body and a physical distortion in the medium are caused (as occurs in the low strain integrity test): compression waves ("P" or longitudinal waves), shear waves ("S" or transverse waves) and waves that propagate on the surface and penetrate relatively little in the pile (Rayleigh waves or "R" waves) [24].

Considering the pile as a bar, the compression wave propagates axially downwards and reflects upwards when it reaches its toe. Other reflections may occur when there is a change in pile material, a change in the area or a sectioning of the pile.

When the piles are not reinforced to their full extent, during the test the stress waves propagate part in a reinforced pile and part in an unreinforced pile. Theoretically, the sudden change in modulus of elasticity and density of the composite section of the pile in the transition can generate a reflection (due to impedance reduction) that can be confused with a pile damage. In this paper, this hypothesis is analyzed using numerical simulations and field test results.

\subsection{Graphical analysis by Beta method}

The magnitude of potential pile damages can be estimated when there is a clear toe signal. In this case, the toe reflection and initial impact amplitudes are equalized and the magnitude estimate of the damage is given by the Beta $(\beta)$ calculation. According to Rausche and Goble [25], Beta $(\beta)$ can be calculated by the relation between the impedance of the section with possible damage and the impedance of the pile without damage.

\section{Materials and experimental program}

It was selected in a database of the company called Protec Engenharia de Projetos, 5 (five) groups of tests in piles with different characteristics. Each group of piles was constructed in a different place from the others but all of them in the metropolitan area of Curitiba, Brazil. For better identification in the rest of this paper, the groups of piles were numbered from 1 to 5 .

In Table 1 the main characteristics of each of them are summarized, extracted from design, besides other input data for the numerical models and later comparison between results. The elastic

\section{Table 1}

Summary of the piles characteristics

\begin{tabular}{|c|c|c|c|c|c|}
\hline \multicolumn{4}{|c|}{ Piles } & \multicolumn{2}{|c|}{ Reinforcement } \\
\hline Group & $\begin{array}{l}\text { Number } \\
\text { of piles }\end{array}$ & $\begin{array}{l}\text { Diameter } \\
\text { (in } \mathrm{m} \text { ) }\end{array}$ & $\begin{array}{l}\text { Length } \\
\text { (in } \mathrm{m} \text { ) }\end{array}$ & $\begin{array}{l}\text { Number of bars } \\
\text { and diameter } \\
\text { (in } \mathrm{mm} \text { ) }\end{array}$ & $\begin{array}{l}\text { Length of the reinforcement } \\
\text { embedded in concrete } \\
\text { (in } \mathrm{m} \text { ) }\end{array}$ \\
\hline 1 & 40 & 0.50 & 13.00 & 6 de 16 & 8.00 \\
\hline 2 & 32 & 0.30 & 15.00 & 4 de 16 & 4.60 \\
\hline 3 & 12 & 0.50 & 10.90 & 5 de 16 & 8.00 \\
\hline 4 & 12 & 0.70 & 20.50 & 5 de 32 & 8.80 \\
\hline 5 & 12 & 0.80 & 21.80 & 12 de 25 & 10.50 \\
\hline
\end{tabular}


Table 2

Additional input data

\begin{tabular}{ccccc}
\hline Group & $\begin{array}{c}\text { Edyn } \\
\text { (in MPa) }\end{array}$ & $\begin{array}{c}\text { tc } \\
\text { (in ms) }\end{array}$ & $\begin{array}{c}\mathbf{F} \\
\text { (in kN) }\end{array}$ & $\begin{array}{c}\text { Function of } \\
\text { amplification } \\
\text { (in times) }\end{array}$ \\
\hline 1 & 40312.20 & 0.63 & 8.97 & 15 \\
2 & 36102.40 & 1.20 & 2.69 & 10 \\
3 & 38768.30 & 1.11 & 3.53 & 10 \\
4 & 36793.80 & 0.46 & 16.77 & 10 \\
5 & 33989.70 & 0.51 & 8.87 & 10 \\
\hline
\end{tabular}

properties of the soil: modulus of elasticity (Es) and the Poisson coefficient (vs) in addition to the specific mass ( $\rho s)$ were estimated based on the results of SPTs.

Poisson's ratio values of 0.4 and specific mass of $1800 \mathrm{~kg} / \mathrm{m}^{3}$ were adopted for all soil types covered in this research, consistent with values found in the literature [26]. In the case of specific mass, tests performed on samples collected in the field indicate that the value of $1800 \mathrm{~kg} / \mathrm{m}^{3}$ represents a close estimate of reality. In order to estimate the modulus of soil elasticity it was adopted the relation Eu/NSPT,60 $=9$, value close to that obtained by Kormann [27] for soils of the Formação Guabirotuba and within the range of values found in Stroud's studies [28] for very low degrees of loading. As the low strain integrity test is characterized by being a low strain and dynamic test, the correlation with large strain field tests such as SPT and which mainly affect the initial layers (such as plate load tests) is not accurate. We then chose to estimate these parameters for the numerical simulations based on correlations obtained from the SPT tests and subsequently proceed with a retro-analysis comparing the results obtained in the numerical models with the damping of the signals identified in the results of the tests. The results indicated that the properties assigned to the soil generated damping in the signals in the simulations very close to those observed in the tests.

To conclude the collection of input data, it is needed: specific mass of the concrete of the pile (assumed an average along the length of the pile equal to $2300 \mathrm{~kg} / \mathrm{m}^{3}$ ) and the Poisson's ratio of the concrete equal to 0.20 according to ABNT NBR 6118 [29].

Besides that, the values summarized in Table 2 are required: dynamic elastic modulus of the concrete (Edyn) (obtained by retroanalysis from the average wave speeds observed in the tests in each group of piles); time in which the hammer remains in contact with the top of the pile (tc) assumed to be equal to the initial wavelength obtained by retro-analysis on the reflectograms of the tests performed on the piles and the maximum load $(F)$ applied at the top of the pile also obtained by the average observed in the reports of the tests. It is important to note that the exponential amplification functions that were adopted in the models are the same as the ones used in the field results treatments.

With the properties calibrated, the results obtained in the field tests in Groups 1 to 5 were compared with the results of the numerical simulations in relation to the influence of the reinforcement. To expand the analyzes, from each of the 5 (five) simulations were derived another 3 (three), parametric, in which only one item was varied in the models of origin: the steel/concrete rate. Table 3 summarizes the simulations performed.

The variations in the steel/concrete rate observed in the other simulations not highlighted in Table 3 followed the following logic: to simulate the influence on the results, maintaining all other properties calibrated with the field results, of the variation of the reinforcement ratio (relation between the area of steel and concrete area) to $0.50 \%$, the minimum required by ABNT NBR 6122 [1], to $4.00 \%$ and to the maximum allowable per standard (8.00\%).

\section{Results and discussions}

From Figure 1 to Figure 5, the results obtained in simulations 1 to 20 were indicated, where it was observed that the amplification functions of the signals adopted in the treatment of the field results and maintained in the numerical simulations were not enough to equal the amplitude of the signal of toe with the amplitude of the initial signal.

\section{Table 3}

Summary of the numerical simulations performed for comparison with field results

\begin{tabular}{ccccccccc}
\hline Simulation & $\begin{array}{c}\Phi \\
\text { (in } \mathrm{m})\end{array}$ & $\begin{array}{c}\text { Steel/ } \\
\text { concrete } \\
(\%)\end{array}$ & Simulation & $\begin{array}{c}\Phi \\
\text { (in } \mathrm{m})\end{array}$ & $\begin{array}{c}\text { Steel/ } \\
\text { concrete } \\
(\%)\end{array}$ & Simulation & $\begin{array}{c}\Phi \\
\text { (in } \mathrm{m} \text { ) }\end{array}$ & $\begin{array}{c}\text { Steel/ } \\
\text { concrete } \\
(\%)\end{array}$ \\
\hline 1 & 0.30 & 0.50 & 8 & 0.50 & 8.00 & 15 & 0.70 & 4.00 \\
$2 *$ & 0.30 & 1.14 & 9 & 0.50 & 0.50 & 16 & 0.70 & 8.00 \\
3 & 0.30 & 4.00 & $10^{* * *}$ & 0.50 & 0.61 & 17 & 0.80 & 0.50 \\
4 & 0.30 & 8.00 & 11 & 0.50 & 4.00 & $18^{* * * * *}$ & 0.80 & 1.17 \\
5 & 0.50 & 0.50 & 12 & 0.50 & 8.00 & 19 & 0.80 & 4.00 \\
$6 * *$ & 0.50 & 0.51 & 13 & 0.70 & 0.50 & 20 & 0.80 & 8.00 \\
7 & 0.50 & 4.00 & $14 * * * *$ & 0.70 & 1.04 & - & - & - \\
\hline
\end{tabular}

${ }^{*}$ comparable to piles of Group 2; ** comparable to piles of Group 3; *** comparable to piles of Group 1; **** comparable to piles of Group 4; 


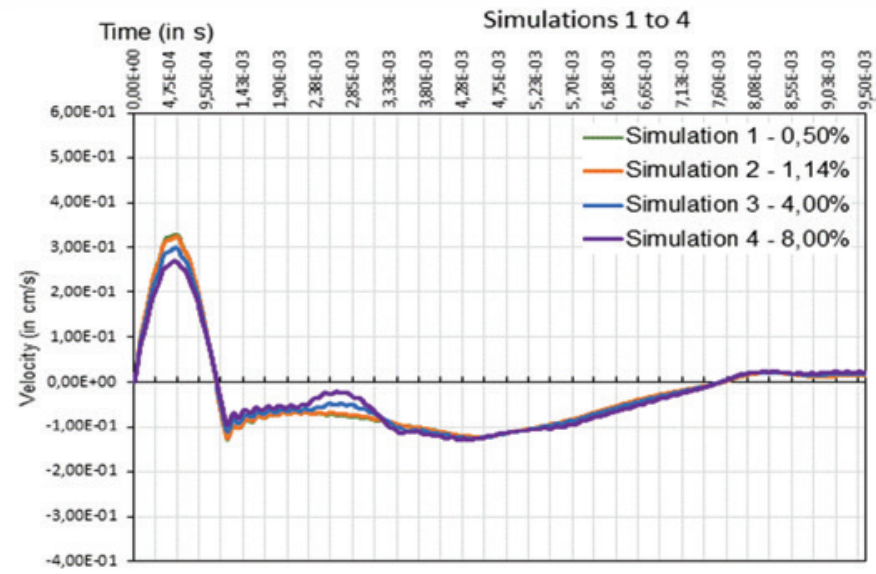

Figure 1

Reflectograms obtained in simulations 1 to 4

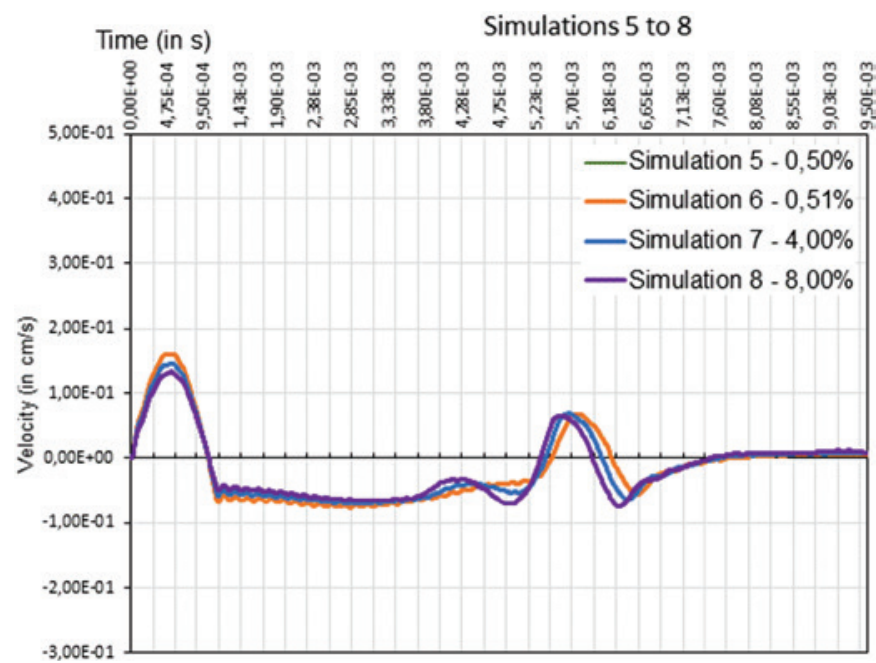

Figure 2

Reflectograms obtained in simulations 5 to 8

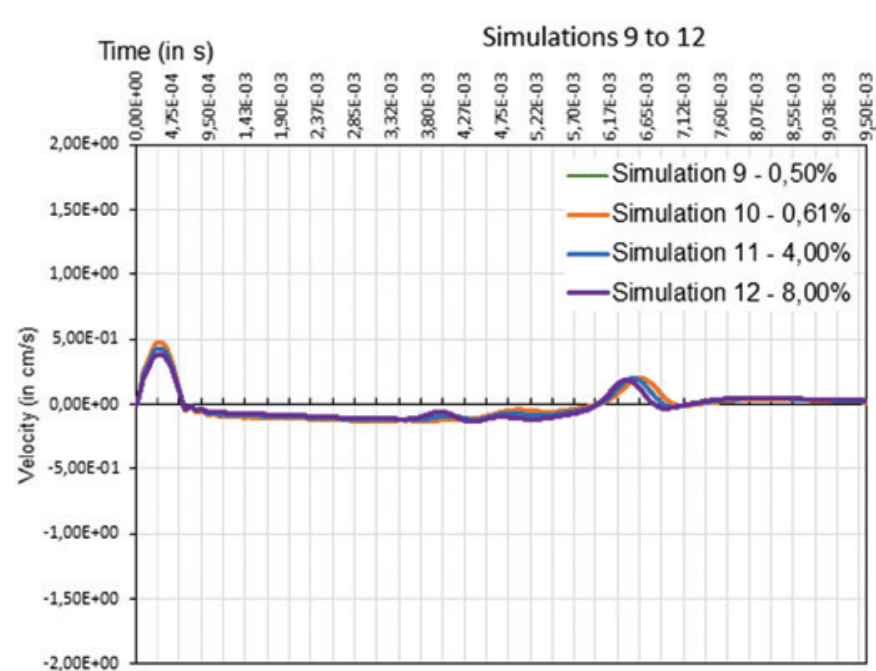

Figure 3

Reflectograms obtained in simulations 9 to 12
This was done to allow a comparative analysis between field results and simulations. It is possible to demonstrate that, with this, the analysis by the Beta method, that is based on the relation between amplitudes of the peaks observed in the reflectogram, proposed by Rausche and Goble [25], with graphical data collection, was impaired, especially when the transition from the reinforced to the unreinforced part of the pile is located at relevant depths at the pile, when the steel/concrete rate is high and when the damping effects generated by the soil are high.In the cases studied, the Beta values calculated graphically directly from the reflectograms indicated in Figures 1 to 5 are $0.45 \%$ to $18.60 \%$ greater than the Beta values obtained analytically. Thus, in Table 4 are indicated Beta values obtained analytically or graphically with corrected amplification functions.

The simulations carried out illustrate that disregarding the modulus of elasticity and specific mass variation between the reinforced and unreinforced sections of the pile may result in the false conclusion

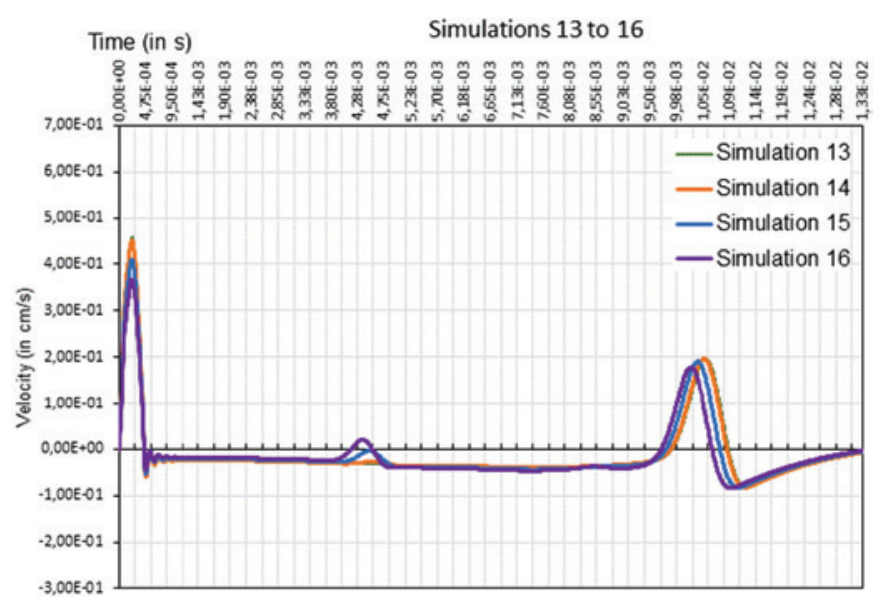

Figure 4

Reflectograms obtained in simulations 13 to 16

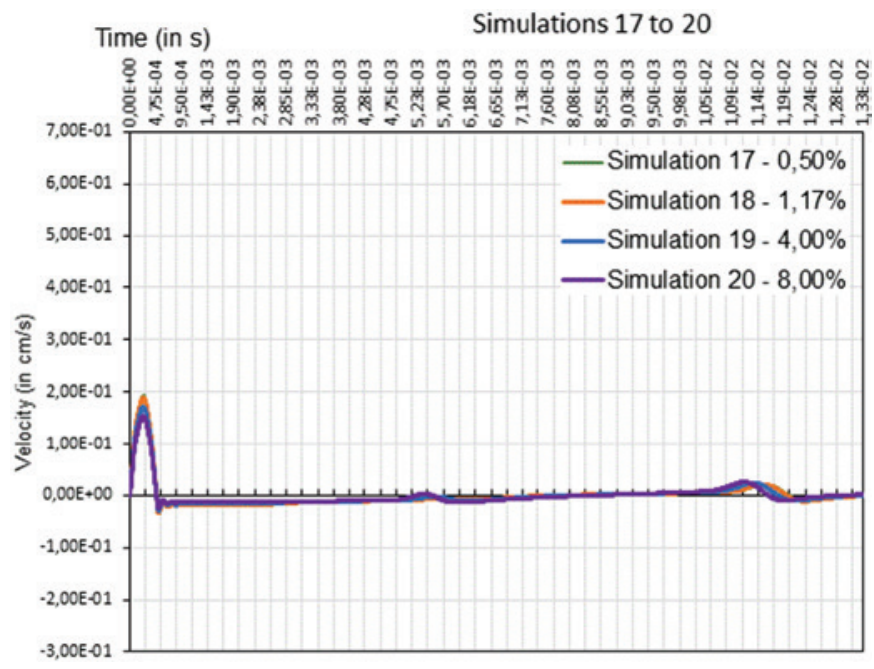

Figure 5

Reflectograms obtained in simulations 17 to 20 
Table 4

Summary of Beta values (\%) obtained in Simulations 1 to 20

\begin{tabular}{ccc}
\hline Simulation & $\begin{array}{c}\text { Beta } \\
(\%)\end{array}$ & $\begin{array}{c}\text { Classification using Rausche } \\
\text { and Goble (1979) }\end{array}$ \\
\hline 1 & 98.24 & Slightly damaged \\
2 & 96.05 & Slightly damaged \\
3 & 87.41 & Slightly damaged \\
4 & 77.72 & Significantly damaged \\
5 & 98.31 & Slightly damaged \\
6 & 98.27 & Slightly damaged \\
7 & 87.98 & Slightly damaged \\
8 & 78.61 & Significantly damaged \\
9 & 98.36 & Slightly damaged \\
10 & 98.00 & Slightly damaged \\
11 & 88.31 & Slightly damaged \\
12 & 79.13 & Significantly damaged \\
13 & 98.24 & Slightly damaged \\
14 & 96.41 & Slightly damaged \\
15 & 87.55 & Slightly damaged \\
16 & 77.93 & Significantly damaged \\
17 & 98.13 & Slightly damaged \\
18 & 95.74 & Slightly damaged \\
19 & 86.85 & Slightly damaged \\
20 & 76.87 & Significantly damaged \\
\hline
\end{tabular}

that the pile is damaged at the transition point. For conventional rates steel/concrete, below $4 \%$ (which still represents a high density of reinforcement such as 9 bars of $20 \mathrm{~mm}$ in a $30 \mathrm{~cm}$ diameter pile) a quantitative analysis by the Beta method and classified by Rausche and Goble [25] would lead to the conclusion of a slight damage to the pile.

\subsection{Comparisons with field results}

In the reflectograms obtained from low strain integrity field tests it was possible to identify a clear reflection in the region of the tip of the reinforcement in the piles of Group 2. In the Table 5 are indicated the amplitudes and values of Beta obtained graphically from the reports of each of the piles that form the group mentioned, as well as what would be the classification of the damage by Rausche and Goble [25] disregarding the influence of the reinforcement bars.

From the 32 piles tested 12 showed relations between the amplitude of the initial wave generated by the blow of the hammer and the amplitude of the variation of particle velocity generated in the approximate region of the tip of the reinforcement bars of the pile very close to those found in the numerical model. Twenty-one (21) piles would present a classification by Rausche and Goble [25] equal to that obtained numerically (slightly damaged), 10 worst (significant damage and seriously damaged) and 1 would

\section{Table 5}

Summary of Beta values (\%) obtained in the piles of Group 2

\begin{tabular}{|c|c|c|c|c|}
\hline Pile & $\begin{array}{c}\text { Amplitude of } \\
\text { the initial peak } \\
(\mathrm{cm} / \mathrm{s})\end{array}$ & $\begin{array}{l}\text { Average amplitude } \\
\text { of the reflected peak } \\
(\mathrm{cm} / \mathrm{s})\end{array}$ & $\begin{array}{l}\text { Beta } \\
(\%)\end{array}$ & Classification \\
\hline E37 & 0.547 & 0.162 & 74.20 & Significant damage. \\
\hline E38 & 0.690 & 0.098 & 86.74 & Slightly damaged \\
\hline E39 & 0.464 & 0.023 & 95.16 & Slightly damaged \\
\hline E40 & 0.545 & 0.122 & 79.87 & Slightly damaged \\
\hline E45 & 0.502 & 0.073 & 86.44 & Slightly damaged \\
\hline E46 & 0.300 & 0.256 & 40.19 & Seriously damaged \\
\hline E47 & 0.390 & 0.182 & 62.16 & Significant damage \\
\hline E48 & 0.444 & 0.064 & 86.55 & Slightly damaged \\
\hline E49 & 0.312 & 0.064 & 81.40 & Slightly damaged \\
\hline E50 & 0.413 & 0.370 & 38.13 & Seriously damaged \\
\hline E51 & 0.373 & 0.200 & 57.72 & Seriously damaged \\
\hline E52 & 0.395 & 0.049 & 88.32 & Slightly damaged \\
\hline E53 & 0.624 & 0.143 & 79.44 & Significant damage \\
\hline E54 & 0.372 & 0.020 & 94.76 & Slightly damaged \\
\hline E55 & 0.419 & - & - & No damage. \\
\hline E68 & 0.487 & 0.049 & 90.42 & Slightly damaged \\
\hline E69 & 0.373 & 0.030 & 92.27 & Slightly damaged \\
\hline E70 & 0.494 & 0.106 & 80.62 & Slightly damaged \\
\hline E71 & 0.426 & 0.045 & 89.97 & Slightly damaged \\
\hline E72 & 0.279 & 0.068 & 78.27 & Significant damage \\
\hline E73 & 0.516 & 0.167 & 72.14 & Significant damage \\
\hline E74 & 0.375 & 0.068 & 83.37 & Slightly damaged \\
\hline E75 & 0.409 & 0.038 & 91.12 & Slightly damaged \\
\hline E76 & 0.270 & 0.024 & 91.49 & Slightly damaged \\
\hline E77 & 0.283 & 0.011 & 96.19 & Slightly damaged \\
\hline E78 & 0.313 & 0.016 & 95.02 & Slightly damaged \\
\hline E79 & 0.370 & 0.019 & 94.99 & Slightly damaged \\
\hline E80 & 0.301 & 0.015 & 95.14 & Slightly damaged \\
\hline E81 & 0.244 & 0.045 & 83.11 & Slightly damaged \\
\hline E82 & 0.276 & 0.083 & 73.86 & Significant damage \\
\hline E85 & 0.426 & 0.042 & 90.60 & Slightly damaged \\
\hline E92 & 0.518 & 0.162 & 72.95 & Significant damage \\
\hline
\end{tabular}


be classified as with no damage. Using the classification proposed by Rausche and Goble [25], therefore, 10 piles with possible significant or serious damages could be selected for additional testing or even reinforcement. However, as explained in the following paragraphs, disregarding the variation of the modulus of elasticity between the reinforced and the unreinforced parts of the piles, in addition to other factors such as the densification of the concrete at the tip of the reinforcement contribute to these results being erroneously interpreted.

On average, a relation between initial and reinforcement tip amplitudes was found to be lower than that obtained numerically (resulting in an average beta equal to $81.37 \%$ ), indicating that at the end of the reinforcement cage there may be a trend towards greater densification of the concrete than that considered in the numerical simulations (possibly due to the confinement generated by the bars) followed by a reduction in density and modulus of elasticity. A factor that helps to prove this hypothesis is that in piles E46, E50 and E55, dynamic loading tests were carried out with 13.6 kN hammers. The results of maximum resistance mobilized (calculated by the CAPWAP method) were $924 \mathrm{kN}, 869 \mathrm{kN}$ and $1077 \mathrm{kN}$, respectively, all satisfactory therefore (working load of $260 \mathrm{kN}$ ). It was observed that the piles E46 and E50 were the ones that presented the lowest Beta percentage among the analyzed ones and the E55 the largest (did not show impedance variations between the reinforced and unreinforced sections) and, nevertheless, the resistance results were satisfactory for all. It is less likely, therefore, that the larger amplitudes of the waves reflected in the transition from the reinforced part to the unreinforced have been generated by large changes in the piles cross sections since there was no significant variation of resistance between the piles that presented greater variation of impedance (E46 and E50) than the one with the lowest impedance variation (E55).

Differently from what happened in the piles of Group 2 , in the piles of Groups 1, 3, 4 and 5 it was not possible to identify a clear reflec- tion in the reinforcement cage tip for comparison with the numerical simulations $6,10,14$ and 18 . It is difficult to distinguish a peak of velocity that may have been caused by the variation of modulus of elasticity and specific mass at that location. Contribute to this situation: the transition between the reinforced and unreinforced parts of the piles in simulation 2 (Group 2) are closer to the top of the pile $(4.60 \mathrm{~m}$ ) than in the others (at least $8.00 \mathrm{~m}$ ) and therefore, the reflected signal is subject to less damping; the piles of the simulations $6,10,14$ and 18 have larger diameter and, consequently, the three-dimensional effects resulting from the difference in between the pile and the hammer diameters are more evident; the steel/ concrete rate is very low and so are the reflections in the transition and it is noticed that intermediate reflections generated either by variations of section of the stake before the transition between the reinforced and unreinforced parts of the pile or by external interferences make it difficult to observe this variation of velocity.

Thus, in the comparisons between simulations and results of field tests, of the 32 piles in which it was possible to identify a velocity peak close to the transition between the reinforced and unreinforced parts of the piles (all belonging to Group 2 of the present paper), $12(37.5 \%)$ presented relations between the amplitude of the initial wave generated by the blow of the hammer and the amplitude of the variation of velocity generated in the approximate location of the tip of the reinforcement bars of the pile very close to those found in the numerical model and, therefore, obtained theoretically. Thus, in 21 of the 32 piles (65.63\%), the analysis of the severity of possible damage by the Beta method would result in the same classification by both the numerical simulation and the field results analysis, in $10(31.25 \%)$ of them worst and in 1 $(3.13 \%)$ it was not possible to identify in the field reflectogram a perceptible variation of velocity in the tip of the reinforcement bars, in which case the pile would be classified as intact in that location. On average, the ratio between initial amplitudes and that generated in the tip of the bars observed in the field tests was lower than

\section{Classification of the possible damages in the transition between reinforced and unreinforced parts} of the pile

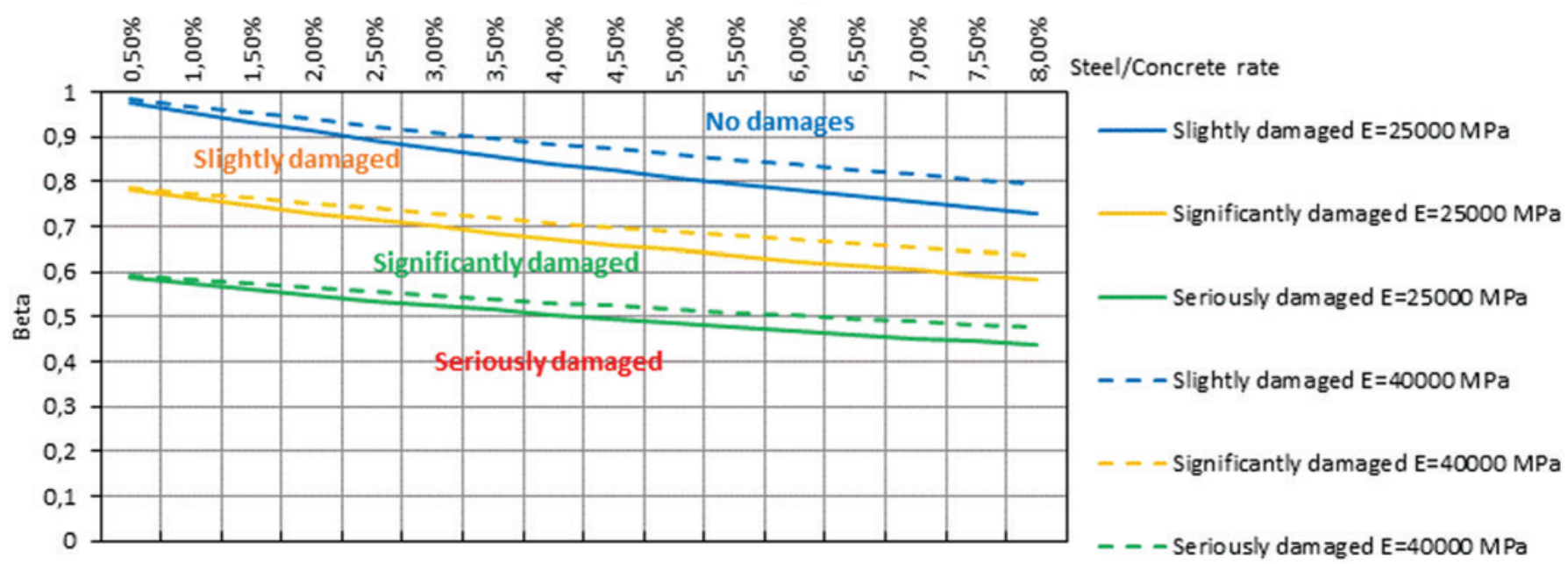

Figure 6

Classification of the possible damages in the transition between reinforced and unreinforced parts of the pile 
that obtained numerically (resulting in an average Beta equal to $81.37 \%$ ). Although in some cases the reflections may have been magnified by diverse effects that are not exclusively generated by the reinforcement, it is possible to affirm that these results indicate that at the tip of the bars there can be a tendency of greater densification of the concrete (due to the confinement generated by the bars, by the presence of concrete spacers and of the transverse reinforcement bars) followed by a reduction of density and modulus of elasticity in the unreinforced part of the piles greater than the theoretical ones. This assumption can be corroborated in future researches with core drilling tests.

\subsection{New classification for possible damages in the tip of the reinforcement bars}

As previously shown, disregarding the modulus of elasticity and specific mass variation between the reinforced and unreinforced parts of the piles may result in the false conclusion that the pile is damaged in that location, especially when the pile has a higher steel/concrete rate. A new classification for analysis of impedance variations detected in the reinforcement bars tip is proposed in this paper, considering the following variables:

a) Modulus of elasticity of the concrete without reinforcement;

b) Specific mass of the concrete without reinforcement;

c) Pile diameter;

d) Steel/concrete rate.

The variation of the specific mass of the concrete without reinforcement has low influence in the calculation of Beta and, therefore, in the results (keeping constant the modulus of elasticity of the concrete in a pile with $4 \%$ of steel/concrete rate and varying the specific mass of the unreinforced concrete from 2000 to $2500 \mathrm{~kg} / \mathrm{m}^{3}$ changes the Beta values in approximately $1.4 \%$ ). It was adopted, in this new classification system, therefore, the value of the specific mass of the unreinforced concrete as being equal to $2400 \mathrm{~kg} / \mathrm{m}^{3}$ [29].

However, the modulus of elasticity has a greater influence. The smaller the modulus of elasticity adopted for concrete without reinforcement, the smaller the calculated Beta and therefore the less favorable to the safety is the proposal of a new classification system. As the Beta values vary significantly considering different values of modulus of elasticity for the concrete, this property was considered as a variable in the proposed system. Thus, simulations were performed considering the following unreinforced concrete modulus of elasticity: $25000 \mathrm{MPa}, 30000 \mathrm{MPa}, 35000 \mathrm{MPa}$ and $40000 \mathrm{MPa}$, within the range of values, therefore, verified in all simulations and field tests of this paper.

Thus, simulations and calculations are made to obtain the theoretical beta factor in the transition between the reinforced and unreinforced parts of the piles for each simulated steel/concrete rate. This first result offers Beta values above which the pile could be considered as "not damaged" (the perceived velocity peak at the tip of the bars embedded into the pile would simply correspond to the theoretical variation of modulus of elasticity and specific mass of a reinforced to an unreinforced concrete and not to an effective pile damage).

To complete the classification system it is necessary to simulate and calculate the range of Beta values that would define a pile with possible slight damages, with possible significant damages and with possible serious damages. By means of retro-analysis, maintaining constant modulus of elasticity and specific mass of the pile, it is possible to calculate that in the classification system proposed by Rausche and Goble [25] it was considered as possible slight damage in the pile a variation of section of the pile of up to $20 \%$, as a possible significant damage a pile section variation of up to $40 \%$ and as serious damage section variations above that value. These values were maintained in the classification proposed here. Thus, a new series of calculations and simulations were performed obtaining, for each steel/concrete rate, what would be the values obtained for the Beta factor varying the section of the pile in $20 \%$ and in $40 \%$. The result of all the simulations performed was compiled in Figure 6.

Therefore, with a reflectogram obtained in a field test with clear toe reflection, an amplification function is applied such as the amplitude of the reflected signal at the toe of the pile is equal to the amplitude of the initial signal (given by the blow of the hammer). If there is an intermediate reflection that coincides with the tip of the bars embedded in the pile, the amplitude of this reflection of the reflectogram is ignored. Once obtained these two values (amplitude of the initial velocity peak and amplitude of the velocity peak in the tip of the reinforcement cage) Equation (6) is applied to calculate the Beta value according to Bungenstab and Beim [3].

$\beta=\frac{1-\alpha}{1+\alpha}$

Where:

$\alpha$ - ratio between the amplitude (A2) observed in the transition of the reinforced to the unreinforced part of the pile and twice the amplitude (A1) of the initial peak (Figure 7).

With this "Beta" value, an estimate of the dynamic modulus of elasticity of the unreinforced concrete used in the pile and the steel/ concrete rate, the classification of possible pile damage is verified in the corresponding graph (see Figure 6). If the point obtained stays in the blue area, the pile may be considered as possibly with no damages, in the yellow area, there is possibly a slight damage in the pile, in the green area possible significant damage and in the red area, possible serious damage. It is important to note that the classification proposed here and the Figure 6 are valid for velocity peaks observed at the point of reinforcement bars tip embedded in a partially reinforced pile.

Note the significant differences in classification of the piles in relation to that proposed by Rausche and Goble [25], especially for higher steel/concrete rates. As for the graphs, they were generated supported largely in theoretical aspects and in the whole background reported in this paper. Nevertheless, it is important to emphasize that a possible user of this classification must know all the considerations reported in [30], the restrictions and limitations of the test and even reclassify the damages.

\section{Conclusions}

From the results of the study, the following conclusions were obtained:

a) It was realized that any analysis based on the evaluation of a possible pile damage by the Beta or equivalent method is impaired without the clear identification of the tip in the test and the correct amplification of the signals in such a way that the 
amplitude of the tip signal is equal to the amplitude of the initial peak generated by a hammer blow. However, when the reflection, caused whether by the reinforcement bars or by some pile damage, occurs a few meters deep in the pile, this problem is minimized since near the top the amplification factor in exponential functions is low (damping effects are smaller than at higher depths).

b) In most of the piles (Groups 1, 3, 4 and 5) it was not clear from the reflectogram of the field test, the reflection due to the variation of modulus of elasticity and the specific mass between the parts. Contributed to the difficulty of identifying this reflection: the high frequency interferences, the higher damping of the signals at higher depths and the relatively low reinforcement rate of the piles (up to $1.17 \%$ ). In the piles with smaller diameter $(0.30 \mathrm{~m})$, with clear identification of tip signal, without signal reflections identified before the tip of the reinforcement bars and with a transition between the reinforced part to the unreinforced part at lower depths (up to $4.60 \mathrm{~m}$ ) it was possible to identify velocity peaks in the signal indicating a variation of impedance that can be attributed to the effect of the reinforcement embedded in the pile concrete.

c) The analyzes carried out showed the possibility of adjusting the classification of potential pile damages proposed by Rausche and Goble [25], based on the Beta method, considering the influence of the reinforcement. This new classification was proposed in item 4.2. This new classification can be tested in future works with subsequent exhumation of the piles or core drilling tests for effective field verification of the methodology.

\section{Acknowledgments}

The authors thank the Coordenação de Aperfeiçoamento de Pessoal de Nível Superior (CAPES) for the promotion of research through the Programa de Pós-Graduação de Engenharia de Construção Civil (PPGECC) of UFPR, as well as the company Protec Engenharia de Projetos for the availability of data used.

\section{References}

[1] ASSOCIAÇÃO BRASILEIRA DE NORMAS TÉCNICAS. Projeto e Execução de Fundações - NBR 6122. Rio de Janeiro, 2010.

[2] SCHAUER, M. \& LANGER, S. Numerical simulations of pile integrity tests using a coupled FEM SBFEM approach. PAMM, v.12, s/n., 2012; p. 547-548.

[3] BUNGENSTAB, F. C., \& BEIM, J. W. (2015). Continuous Flight Auger (CFA) Piles - A Review of the Execution Process and Integrity Evaluation by Low Strain Test. Proceedings of the Pan-American Conference on Soil Mechanics and Geotechnical Engineering, Buenos Aires, 2015, Anais, Buenos Aires, 2015, v.15, p.414-421.

[4] ORDÓÑEZ, J. A. R., \& BOTERO, V. H. R. (2010). Análisis espectral de propagación de ondas para análisis de pruebas de integridad de pilotes. Ingenieria y Universidad, v.10, n.2, 2010; p.139-153.

[5] AMBROSINI, D., \& EZEBERRY, J. Long piles integrity through Impact Echo technique. Proceedings of the Con- greso Argentino de Mecánica Computacional, $24^{\circ}$,Buenos Aires, 2005, Anais, Buenos Aires, 2005, s/v.,p.619-651.

[6] CHAI, H.-Y., WEI C.-F., PHOON K.-K., \& YANG Y.-M. Some observations on the performance of the signal matching technique in assessment of pile integrity. Journal of Nondestructive Evaluation, v.30, n. 4, p.246-258.

[7] LUO, W., CHEN, F., \& HU, J. Improvement of Low Strain Pile Integrity Test. Proceedings of the ASEE (American Society of Engineering Education) Conference, Beijing, 2010, Anais, Beijing, 2010, s/v., p. 583-589.

[8] DING, X., LIU H., LIU J., \& CHEN Y. Wave propagation in a pipe pile for low-strain integrity testing. Journal of Engineering Mechanics, v.137, n 9., 2011; p.598-609.

[9] COSIC, M., FOLIC, B., \& FOLIC, R.. Numerical simulation of the pile integrity test on defected piles. Acta Geotechnica Slovenica, v.11, s/n., 2014; p.4-19.

[10] WANG, Z., WU, Y., \& XIAO, Z. Numerical Assessment of Factors Affecting Waveform Based on Low Strain Testing of Piles. Open Civil Engineering Journal, v.8, s/n., 2014; p.64-70.

[11] HETLAND, J. (2015). Numerical Modelling of a Pile Model Test with Focus on Small-strain Stiffness. Dissertação (mestrado em Engenharia Civil e Ambiental) - Departamento de engenharia civil e de transporte, Norwegian University of Science and Technology, 130p..

[12] HOU, S.-W., HU S.-J., GUO S.-P., \& ZENG Y.-Q. (2016) The Research of Multi-defective Piles for Low Strain Testing and Numerical Simulation. Structures Congress, $16^{\circ}$, Jeju Island, 2016, Anais, Jeju Island, 2016, s/ v., p.1-8.

[13] LIANG, L., RAUSCHE, F. (2011) Quality Assessment Procedure and Classifications of Cast-in-Place Shaft using Low Strain Dynamic Test. Deep Foundations Institute Annual Conference on Deep Foundations, $36^{\circ}$, Boston, 2011, Proceedings, Boston, 2011, s/ v., p.553-562.

[14] WEBSTER, K.; RAUSCHE F.; WEBSTER, S. (2011) Pile and Shaft Integrity Test Results Classification, Mitigation, Acceptance, and/or Rejection. In: Transportation Research Board, $90^{\circ}, 2011$.

[15] CUNHA,R.P.; CAMAPUM DE CARVALHO, J.; SILVA, C.M. (2002) Controle de qualidade e aceitação de estacas moldadas in loco via utilização de ensaios de integridade de estacas (PIT). Congresso Brasileiro de Mecânica dos Solos e Engenharia Geotécnica, $12^{\circ}$, São Paulo, 2002, v.3, p. 1569-1579.

[16] SMITH, E.A.L. Pile-Driving Analysis by the wave equation. ASCE Paper, v.127,s/nº, 1964; p.1145.

[17] LYSMER, J.F.E.R., \& RICHART, F.E. Dynamic Response of Footings to Vertical Loading. Journal of the Soil Mechanics and Foundations Division, v.92, n`1, 1966; p.65-91.

[18] NOVAK, M. Dynamic stiffness and damping of piles. Canadian Geotechnical Journal, v.11, n.4, 1974 p.574-598.

[19] SIMONS, H.A., \& RANDOLPH, M.F. (1984). A New Approach to One-Dimensional Pile Driving Analysis, Cambridge: Cambridge Univ., Engineering Dep, v. 159, 1984.

[20] YU, C.-P., \& LIAO, S.-T. Theoretical basis and numerical simulation of impedance log test for evaluating the integrity of columns and piles. Canadian geotechnical journal, v.43, n.12, 2006; p.1238-1248. 
[21] NEWMARK, N. M. A method of computation for structural dynamics. Journal of Engineering Mechanics - ASCE, v.85, n.3 ,1959; p.67-94.

[22] HILBER, H. M., HUGHES, T. JR., \& TAYLOR, R. L. Improved numerical dissipation for time integration algorithms in structural dynamics. Earthquake Engineering \& Structural Dynamics, v.5, n. 3, 1977; p. 283-292.

[23] LIAO, S. T., \& ROESSET, J. M. Dynamic response of intact piles to impulse loads. International Journal for Numerical and Analytical Methods in Geomechanics, v.21, s/n., 1997; p.255-275.

[24] FINNO, R. J., GASSMAN, S. L., \& OSBORN, P. W. (1997). Non-destructive evaluation of a deep foundation test section at the Northwestern University national geotechnical experimentation site. (Relatório/1997), Federal Highway Administration Office, Northwestern University, Evanston, Illinois, EUA, 306p.

[25] RAUSCHE, F., \& GOBLE, G. Determination of pile damage by top measurements. American Society for Testing and Materials: Philadelphia, n.670, 1979; p.500-506.

[26] BOWLES, J. E. (1977) Foundation analysis and design McGraw Hill, Ltda.

[27] KORMANN, A. C. M. (2002) Ensaio de integridade de estacas (PIT) - conceitos básicos. Workshop Controle de Qualidade de Fundações através de Provas de Carga Dinâmicas e Verificação de Integridade Estrutural, Sinduscon-SP e ABMS. São Paulo, 2002.

[28] STROUD, M. A. (1989) The standard penetration test - its application and interpretation. Conference on Penetration Testing in the UK, Londres, 1989. Anais... Londres: Thomas Telford, 1989.

[29] ASSOCIAÇÃO BRASILEIRA DE NORMAS TÉCNICAS. Projeto de estruturas de concreto - Procedimento - NBR 6118. Rio de Janeiro, 2014.

[30] PASQUAL, R.P.S. (2018) Ensaios de baixa deformação para avaliação da integridade de estacas (PIT)-desenvolvimento de modelos numéricos por elementos finitos e contribuições às análises de resultados. Dissertação (Mestrado Engenharia de Construção Civil)-Universidade Federal do Paraná, 2018, 209 p. 